\title{
Element Determination in Pharmaceuticals Using Direct Solid Analysis- Electrothermal Vaporization Inductively Coupled Plasma Optical Emission Spectrometry
}

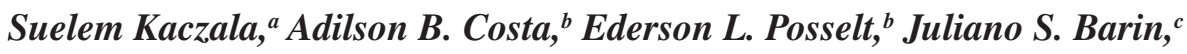 \\ Erico M. M. Flores ${ }^{a}$ and Valderi L. Dressler ${ }^{*, a}$ \\ ${ }^{a}$ Departamento de Química, Universidade Federal de Santa Maria, \\ 97105-900 Santa Maria-RS, Brazil \\ ${ }^{b}$ Departamento de Biologia e Farmácia, Universidade de Santa Cruz do Sul, \\ 96815-900 Santa Cruz do Sul-RS, Brazil \\ ${ }^{c}$ Departamento de Alimentos, Universidade Federal de Santa Maria, \\ 97105-900 Santa Maria-RS, Brazil
}

\begin{abstract}
A solid sampling electrothermal vaporization inductively coupled plasma optical emission spectrometry (ETV-ICP OES) method for determination of $\mathrm{As}, \mathrm{Cd}, \mathrm{Cr}, \mathrm{Cu}, \mathrm{Mn}, \mathrm{Mo}, \mathrm{Ni}, \mathrm{Pb}, \mathrm{Pd}$, $\mathrm{Pt}, \mathrm{Rh}, \mathrm{Ru}$ and $\mathrm{V}$ in pharmaceuticals is proposed. Tricyclic pharmaceuticals were directly analyzed due to their difficult decomposition with acids. Pyrolysis and vaporization temperature, sample mass, and reaction gas (Freon) flow rate were evaluated. The effect of organic and inorganic compounds was evaluated for matrix matching. The limits of detection ranged from $0.04 \mu \mathrm{g} \mathrm{g}^{-1}$ $(\mathrm{Cu})$ to $107 \mu \mathrm{g} \mathrm{g}^{-1}$ (As) and the relative standard deviation was lower than $10 \%$. The investigated elements were not detected in the analyzed samples with the exception of $\mathrm{Cr}$ in cyclobenzaprine hydrochloride. Since there was no certified reference materials available for metals and metalloids in pharmaceuticals, the accuracy of the method was evaluated by an independent technique and by analyte recovery. Inductively coupled plasma mass spectrometry was employed for analyte determination after sample decomposition by microwave induced combustion. The agreement of the results found by both techniques was better than $87 \%$ and analyte recoveries ranged from 91 to $103 \%$.
\end{abstract}

Keywords: pharmaceuticals, metals, ETV-ICP OES

\section{Introduction}

Pharmaceuticals are recommended by both modern and traditional medicine. They are commonly present in human life to prevent and treat several diseases. According to the World Health Organization, ${ }^{1}$ pharmaceuticals must be safe, effective and of good quality for use in life.

Some pharmaceuticals are metal-based as for instance cis-platinum and carboplatin used as therapeutic agent in anticancer therapy or barium sulfate used as X-ray contrast agent. Although in these pharmaceuticals the metals are active ingredients, in others metals and metalloids they are not desired. ${ }^{2}$

Despite efforts of pharmaceuticals industries, toxic elements may be present as impurities in the final product.

*e-mail: vdressler@gmail.com
These impurities may be originated from several sources, like manufacturing equipment, excipients or reagents used during the synthesis, mostly metal catalysts. ${ }^{3}$

It is known that some elements are extremely toxic for human health, even at low concentrations. The International Conference on Harmonization $(\mathrm{ICH})^{3}$ elaborated a guideline where elements were divided in classes according to level of safety concern. The first class includes elements that are significantly toxic ( $\mathrm{As}, \mathrm{Cd}, \mathrm{Hg}, \mathrm{Pb}$ ). The second class is divided in two classes: class $2 \mathrm{~A}(\mathrm{Co}, \mathrm{Mo}, \mathrm{Se}, \mathrm{V})$ and class 2B (Ag, Au, Ir, Os, Pd, Pt, Rh, Ru, Tl). The latter class includes elements that are more or less toxic depending on the route of administration. The third class includes as impurities elements of relatively low safety concern (Ba, $\mathrm{Cr}, \mathrm{Cu}, \mathrm{Li}, \mathrm{Ni}, \mathrm{Sb}, \mathrm{Sn})$. The fourth class includes elements that have low inherent toxicity, for which there is not an established and permitted daily exposure (Al, B, Ca, Fe, K, 
$\mathrm{Mg}, \mathrm{Mn}, \mathrm{Na}, \mathrm{Zn}$ and $\mathrm{W})$. In general, most cited elements have persistent and cumulative effect in the human body. Therefore, quality control of pharmaceuticals, especially with respect to contamination with toxic elements, is necessary.

The United States Pharmacopoeia (USP), ${ }^{4}$ Brazilian Pharmacopoeia (FBRAS), ${ }^{5}$ and European Pharmacopoeia (Ph.Eur. $)^{6}$ describe several assays for using in the quality control of pharmaceuticals. Regarding to potentially toxic elements, the limit test is usually recommended. This test is based on the visual comparison of the precipitate produced when thioacetamide is added to an aliquot of the sample solution (usually $1.0 \mathrm{~g}$ of sample in $25 \mathrm{~mL}$ ) and to a standard solution of $\mathrm{Pb}$ (usually $2.0 \mathrm{~mL}$ of solution containing $10 \mathrm{mg} \mathrm{L}^{-1}$ of $\mathrm{Pb}$ ). The main drawback of this method is its lack of specificity and sensitivity, since there are toxic and non-toxic elements that may be precipitated by thioacetamide. On the other hand, not all analyte elements can precipitate with thioacetamide or the color of the precipitate may be different from that in the $\mathrm{Pb}$ standard solution. Furthermore, the elements must be as free ions in solution. Therefore, other methods for element determination must be developed in order to have more reliable results. Methods using flame atomic absorption spectrometry (FAAS), inductively coupled plasma optical emission spectrometry (ICP OES) and inductively coupled plasma mass spectrometry (ICP-MS) have been proposed by the pharmacopoeias for element determination. ${ }^{4-6}$ In this case, samples must be in solution, preferentially decomposed to minimize interferences in measurement step.

Several authors have proposed methods for element determination in pharmaceuticals and respective raw materials involving the use of FAAS, ${ }^{7}$ graphite furnace atomic absorption spectrometry (GF AAS) ${ }^{8}$ ICP OES,${ }^{9}$ total reflectance X-ray fluorescence (TXRF) ${ }^{10}$ and laser induced breakdown spectrometry (LIBS). ${ }^{11}$ Nevertheless, the ICP-MS technique is very appropriate for element determination in pharmaceuticals ${ }^{12,13}$ due to its multielemental capability and excellent sensitivity (detection limits in the range of $\mathrm{n} \mathrm{L} \mathrm{L}^{-1}$ or $\mathrm{ng} \mathrm{g}^{-1}$ ).

Excepting TXRF and LIBS, pharmaceutical samples are preferably analyzed when they are solubilized and the respective solutions analyzed. Therefore, direct solubilization of the pharmaceutical in water or another solvent is carried out. Decomposition of the pharmaceutical sample with inorganic acids is also used for reducing the organic content and ensure accurate results. ${ }^{14,15}$ However, pharmaceuticals such as tricyclic antidepressants are difficult to decompose by acid even at high temperature and pressure. When nitric acid is used, nitro groups can bind the benzene ring and produce very insoluble compounds ${ }^{16}$ Thus, the conventional acid decomposition becomes ineffective. Sample combustion in open vessel and element absorption in a solvent are not recommended, by considering the analyte loss in the first case and the organic matrix that remains in the solution in the latter. In this sense, microwave induced combustion (MIC) is useful as already demonstrated. ${ }^{16-18}$

Direct analysis of solid sample has been proposed, which simplifies the analysis and reduces sample contamination and analyte losses of volatile elements. ${ }^{19}$ Electrothermal vaporization (ETV) associated with ICP OES or ICP-MS allows direct solid sampling analysis. Several applications dealing with biological, ${ }^{20}$ environmental, ${ }^{21}$ geological, ${ }^{22}$ polymers, ${ }^{23}$ refractory materials, ${ }^{24}$ and forensic samples ${ }^{25}$ analysis are reported. Nevertheless, only one work about direct element determination in solid pharmaceuticals was found. ${ }^{26}$ However, in such work, a slurry of the sample under sonication was introduced in the graphite tube in the ETV system hyphenated with ICP-MS. To the best of our knowledge, determination of elemental impurities present in pharmaceuticals by electrothermal vaporization inductively coupled plasma optical emission spectrometry (ETV-ICP OES) has not been reported. Therefore, in the present work, the use of ETV-ICP OES is proposed for As, $\mathrm{Cd}, \mathrm{Cr}, \mathrm{Cu}, \mathrm{Mn}, \mathrm{Mo}, \mathrm{Ni}, \mathrm{Pb}, \mathrm{Pd}, \mathrm{Pt}, \mathrm{Rh}, \mathrm{Ru}$ and $\mathrm{V}$ determination in ten different types of pharmaceuticals, including matrices that are difficult to decompose by acids.

\section{Experimental}

Instrumentation

An electrothermal vaporization unit (Spectral Systems, model ETV-4000c, Germany) was used for solid sampling analysis. Pyrolytic coated graphite tubes and graphite platforms (both from Spectral Systems) were used. In this way, the diffusion of metals on graphite wall and oxidation of graphite is reduced. ${ }^{27}$ The graphite tubes are longitudinally heated and the temperature range on the ETV system can be varied from room temperature up to $3000{ }^{\circ} \mathrm{C}$. The carrier, modifier and bypass-gas flow rates were adjusted as necessary. A polytetrafluoroethylene (PTFE) transfer line of $100 \mathrm{~cm}$ length and $0.6 \mathrm{~cm}$ i.d. was used to connect the ETV device to the ICP torch. Wet samples were dried by using a drying bank (Spectral Systems). A dual view optical spectrometer (PerkinElmer, model Optima 4300DV, USA), with a quartz torch and alumina injector tube (2.0 mm i.d.) was used. Argon with $99.996 \%$ (stored as liquid in tank) purity (White Martins, São Paulo, Brazil) was used as protection, carrier and bypass-gas on the ETV device. The same argon gas was used as plasma 
and auxiliary gas in the ICP OES instrument. The ETV and ICP OES parameters are summarized in Table 1.

A micro-balance (Sartorius, model M2P, Germany) with a resolution of $0.001 \mathrm{mg}$ and maximum capacity of $2 \mathrm{~g}$ was used for sample weighing. A SpeedWave four (Berghof,

Table 1. ETV-ICP OES and ICP-MS instrumental parameters

\begin{tabular}{|c|c|c|}
\hline Instrument & Parameter & Setting \\
\hline \multirow[t]{4}{*}{$\overline{\mathrm{ETV}}$} & Carrier-gas / $\left(\mathrm{L} \mathrm{min}^{-1}\right)$ & 0.14 \\
\hline & Bypass-gas / $\left(\mathrm{L} \mathrm{min}^{-1}\right)$ & 0.40 \\
\hline & 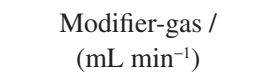 & $0.5-5.0$ \\
\hline & Transferline i.d. / mm & 6 \\
\hline \multirow[t]{6}{*}{ ICP OES } & $\begin{array}{l}\text { Radiofrequency } \\
\text { power / W }\end{array}$ & 1500 \\
\hline & $\begin{array}{l}\text { Plasma argon } \\
\text { flow / }\left(\mathrm{L} \mathrm{min}^{-1}\right)\end{array}$ & 15.0 \\
\hline & $\begin{array}{l}\text { Auxiliary argon } \\
\text { flow / }\left(\mathrm{L} \mathrm{min}{ }^{-1}\right)\end{array}$ & 0.2 \\
\hline & Injector tube i.d. / mm & 2.0 \\
\hline & Plasma view & Axial \\
\hline & Wavelength / nm & $\begin{array}{c}\text { As188.979(I), } \\
\text { Cd228.802(I), } \\
\text { Cr283.563(II), } \\
\text { Cu324.752(I), } \\
\text { Mn257.610(II), } \\
\text { Mo202.031(II), } \\
\text { Ni341.476(II), } \\
\text { Pb220.353(II), } \\
\text { Pd340.458(I), } \\
\text { Pt299.797(I), } \\
\text { Rh343.489(I), } \\
\text { Ru349.894(I), } \\
\text { V310.230(II) }\end{array}$ \\
\hline \multirow[t]{11}{*}{ ICP-MS } & $\begin{array}{c}\text { Radiofrequency } \\
\text { power / W }\end{array}$ & 1300 \\
\hline & $\begin{array}{c}\text { Plasma argon } \\
\text { flow / }\left(\mathrm{L} \mathrm{min}^{-1}\right)\end{array}$ & 15.0 \\
\hline & $\begin{array}{l}\text { Auxiliary argon } \\
\text { flow / }\left(\mathrm{L} \mathrm{min}{ }^{-1}\right)\end{array}$ & 1.20 \\
\hline & $\begin{array}{l}\text { Nebulizer argon } \\
\text { flow / }\left(\mathrm{L} \mathrm{min}^{-1}\right)\end{array}$ & 1.04 \\
\hline & $\begin{array}{c}\text { Sampler and skimmer } \\
\text { cones }\end{array}$ & $\mathrm{Pt}$ \\
\hline & Lens voltage mode & Auto lens \\
\hline & Sweeps/Reading & 5 \\
\hline & Reading/Replicate & 3 \\
\hline & Dwell time / ms & 20 \\
\hline & Replicates & 3 \\
\hline & Isotope $/ \mathrm{m} / \mathrm{z}$ & $\begin{array}{c}{ }^{51} \mathrm{~V},{ }^{52} \mathrm{Cr},{ }^{53} \mathrm{Cr},{ }^{55} \mathrm{Mn}, \\
{ }^{58} \mathrm{Ni},{ }^{60} \mathrm{Ni},{ }^{63} \mathrm{Cu},{ }^{65} \mathrm{Cu}, \\
{ }^{75} \mathrm{As},{ }^{98} \mathrm{Mo},{ }^{102} \mathrm{Ru},{ }^{104} \mathrm{Ru}, \\
{ }^{103} \mathrm{Rh},{ }^{106} \mathrm{Pd},{ }^{108} \mathrm{Pd}, \\
{ }^{111} \mathrm{Cd},{ }^{191} \mathrm{Ir},{ }^{193} \mathrm{Ir},{ }^{194} \mathrm{Pt}, \\
{ }^{195} \mathrm{Pt},{ }^{207} \mathrm{~Pb},{ }^{208} \mathrm{~Pb}\end{array}$ \\
\hline
\end{tabular}

Germany) equipped with twelve vessels (TFM) and operated at maximum power, temperature and pressure of $1450 \mathrm{~W}, 230^{\circ} \mathrm{C}$ and 50 bar, respectively, was used to assists the sample decomposition using acid. A Multiwave 3000 (Anton Paar, Austria) equipped with eight quartz vessels and operated at maximum power, temperature and pressure of $1400 \mathrm{~W}, 280{ }^{\circ} \mathrm{C}$ and $80 \mathrm{bar}$, respectively, was used for microwave induced combustion. An ICP-MS spectrometer from PerkinElmer-SCIEX (model Elan DRC II, Canada) equipped with a baffled cyclonic spray chamber and a concentric nebulizer was used for element determination in the solutions of the acid-decomposed samples. Instrumental conditions are shown in Table 1.

Reagents, standards and samples

The water used to prepare the solutions was distillated, deionized and then purified using a Milli-Q system (Millipore, Billerica, USA, $18.2 \mathrm{M} \Omega \mathrm{cm}$ ). $\mathrm{HNO}_{3} 65 \% \mathrm{~m} \mathrm{~m}^{-1}$ (Merck, Darmstadt, Germany) was used for sample decomposition and calibration solutions preparation. This acid was double distilled in a duoPUR 2.01E sub-boiling system (Milestone, Italy). All other reagents were of analytical grade. Calibration solutions were prepared by serial dilution of multielement stock solutions SCP33MS $10 \mathrm{mg} \mathrm{L}^{-1}$ (SCP Science, Canada) and CLMS-3 $10 \mathrm{mg} \mathrm{L}^{-1}$ (Spex CertiPrep, USA) in $\mathrm{HNO}_{3} 0.72 \mathrm{~mol} \mathrm{~L}^{-1}$. The calibration solutions used for determinations by ICP-MS ranged from 0.10 to $10.0 \mu \mathrm{g} \mathrm{L} \mathrm{L}^{-1}$. Aliquots of 0.5 to $25 \mu \mathrm{L}$ of the solutions cotanining the investigated elements were transferred directly on the graphite platform in order to obtain the calibration curves for ETV-ICP OES.

Freon R12 $\left(\mathrm{CCl}_{2} \mathrm{~F}_{2}\right)$ was used as reaction gas. Citric acid $\left(\mathrm{C}_{6} \mathrm{H}_{8} \mathrm{O}_{7}\right.$, Synth, Brazil), ascorbic acid $\left(\mathrm{C}_{6} \mathrm{H}_{8} \mathrm{O}_{6}\right.$, Belga Química, Brazil), oxalic acid $\left(\mathrm{C}_{2} \mathrm{H}_{2} \mathrm{O}_{4}\right.$, Nuclear, Brazil), ethylenediaminetetraacetic acid $\left(\mathrm{C}_{10} \mathrm{H}_{16} \mathrm{~N}_{2} \mathrm{O}_{8}\right.$, Reagen, Brazil) and sodium chloride ( $\mathrm{NaCl}$, Merck, Germany) were also evaluated for matrix matching. Ammonium nitrate $\left(\mathrm{NH}_{4} \mathrm{NO}_{3}\right.$, SigmaAldrich) 6 mol L-1 was used as igniter for MIC. Oxygen with purity of $99.9991 \%$ (White Martins, Brazil) was used to pressurize the quartz vessels for MIC.

Ten samples of pharmaceuticals, including amitriptyline hydrochloride, carbamazepine, clozapine, cyclobenzaprine hydrochloride, imipramine hydrochloride, ketotifen fumarate, loratadine, nortriptyline hydrochloride, promethazine hydrochloride and tetracycline hydrochloride, were obtained from local drugstores. The samples were in powder or tablet form. Those in tablet form were grounded in an agate mortar to have particles size lower than $65 \mu \mathrm{m}$. Then, they were stored in decontaminated plastic vials. The pharmaceuticals in powder form were analyzed without any treatment. 
Procedures

\section{ETV-ICP OES}

The ETV-ICP OES method was optimized in order to find conditions that would allow the analysis of all the pharmaceutical samples. A steel tweezers provided by the ETV manufacturer was used for graphite platform handling whereas a steel spatula was used to tranfer the sample to the platform. Before use, the empty graphite platform was cleaned by submiting it to the heating program of the ETV at temperature up to $2400{ }^{\circ} \mathrm{C}$. The amitriptyline hydrochloride sample was used for method development. To this end, $2.5 \mathrm{mg}$ of sample were weighed into the graphite platform and submitted to the heating program of the ETV. For better signal visualization, the sample was spiked with $5 \mu \mathrm{L}$ of solution containing $300 \mathrm{ng}$ of As, $150 \mathrm{ng}$ of Mo and $30 \mathrm{ng}$ of the other analytes. This solution was added onto the sample on the graphite platform and then dried using the drying bank set at $90{ }^{\circ} \mathrm{C}$. A graphite platform containing only $5 \mu \mathrm{L}$ of $\mathrm{HNO}_{3} 0.72 \mathrm{~mol} \mathrm{~L}^{-1}$ was used as blank. For standard addition calibration, different volumes of calibration solutions were added onto the sample previously weighed in the graphite platform. When solution or sample spiked with the anlaytes were analyzed, they were dried before introducing the graphite platform into the furnace.

The analytes signal intensities were obtained by setting the ICP OES spectrometer for 40 readings during $0.01 \mathrm{~s}$ each. Peak area was used for signal and data processing, which was possible by means of a software developed (Sisvap, Brazil) in order to integrate the transient signals.

\section{Sample preparation by MIC}

Since there was no certified reference materials (CRM) available, results were validated by comparison with those obtained by ICP-MS after sample decomposition using MIC and by analyte recovery test. More details of the MIC procedure are described by Flores et al. ${ }^{28}$ Briefly, pellets of samples $(125 \mathrm{mg}$ ) were prepared by pressing the powdered material in a manual hydraulic press (Specac, UK) set at 5 ton for $30 \mathrm{~s}$. The pellets were transferred to the quartz sample holder containing a purified filter paper humidified with $50 \mu \mathrm{L}$ of $6.0 \mathrm{~mol} \mathrm{~L}^{-1} \mathrm{NH}_{4} \mathrm{NO}_{3}$ solution. The $\mathrm{NH}_{4} \mathrm{NO}_{3}$ acts as igniter. Quartz flasks were pressurized with $\mathrm{O}_{2}$ to 20 bar. A $14.4 \mathrm{~mol} \mathrm{~L}^{-1} \mathrm{HNO}_{3}$ solution $(6 \mathrm{~mL})$ was used as absorbing solution. The microwave oven program used for MIC consisted of an irradiation step for 5 min at $1400 \mathrm{~W}$, followed by a cooling step for $20 \mathrm{~min}(0 \mathrm{~W})$. The absorbing solution was further diluted to $30 \mathrm{~mL}$ with water and the investigated elements determined in the final solution using ICP-MS

\section{Results and Discussion}

Since carbon is the major constituent of the analyzed samples, the ETV heating program was adjusted in order to eliminate the carbon matrix before the analyte vaporization. It was observed that at temperature from 300 to $350{ }^{\circ} \mathrm{C}$, the sample matrix was almost completely eliminated. This was verified by weight loss after the sample is submited to pyrolysis step. Thus, the furnace was heated up to $200{ }^{\circ} \mathrm{C}$ using a fast temperature ramp and then the temperature was slowly raised to $350{ }^{\circ} \mathrm{C}$ (Table 2). In this way, the organic matter was eliminated and matrix effects reduced as observed by the similarity of the analyte signal profiles in the presence and absence of sample. Additionally, as observed by Detcheva et al. ${ }^{29}$ and Barth et al.,${ }^{24}$ halogencontaining modifiers (such as $\mathrm{CCl}_{2} \mathrm{~F}_{2}$ ) buffer differences related with the analyte chemical form, which may be different in samples and calibration solution. Consequently, the analyte present in the solid sample and in the dried solution has a quite similar vaporization behavior, as observed in the present work.

Table 2. Heating program of the ETV

\begin{tabular}{lccc}
\hline Step & Ramp / s & $\mathrm{T} /{ }^{\circ} \mathrm{C}$ & Hold / s \\
\hline Dry & 5 & 200 & 10 \\
Pyrolysis & 60 & 350 & 15 \\
Vaporization & 0 & 1600 & 20 \\
Cleaning & 10 & 2400 & 5 \\
\hline
\end{tabular}

Modifier evaluation

It is well known that elements such as $\mathrm{Cr}, \mathrm{V}, \mathrm{Mo}, \mathrm{B}$ and $U$ are difficult to vaporize by electrothermal heating in graphite tube since these elements form carbides that are volatilized only at $3000{ }^{\circ} \mathrm{C}$ or higher tempertures..$^{30,31}$ An alternative is to produce more volatile species of these elements, making possible their determination using electrothermal vaporization. To this end, several studies have reported the use of oxinates and halogenated compounds. Ammonium fluoride, PTFE, and halogenated gases as $\mathrm{CCl}_{2} \mathrm{~F}_{2}$ are among the most commonly used halogenated compounds. ${ }^{30}$ In the case of $\mathrm{CCl}_{2} \mathrm{~F}_{2}$, it decomposes at temperature around $700{ }^{\circ} \mathrm{C}$, producing $\mathrm{CF}_{2}, \mathrm{CF}_{3} \mathrm{Cl}, \mathrm{CF}_{4}$, and $\mathrm{C}_{2} \mathrm{~F}_{4}$ radicals, which promote the analyte conversion into volatile halides. ${ }^{32}$ The analyte transport increasing as a consequence of cluster formation is another advantage of using halogen modifiers in ETV. ${ }^{33-35}$ By considering the vaporization temperature, the elements investigated in the present work could be more or less classified in three groups: (i) As and Cd as volatile elements; (ii) Pd, Pt, Rh, 
and $\mathrm{Ru}$ as refractory elements and (iii) $\mathrm{Cr}, \mathrm{Cu}, \mathrm{Mo}, \mathrm{Ni}$ and $\mathrm{V}$ as carbide forming elements.

Freon was used as reaction gas in the present work, whereas the gas flow rate was evaluated in the range of 0.5 to $5.0 \mathrm{~mL} \mathrm{~min}^{-1}$. As expected, the vaporization temperature of several elements decreased drastically in the presence of Freon as a consequence of the formation of halogenated compounds. The influence of the Freon flow rate on As, Cr, $\mathrm{Pd}$ and $\mathrm{Pt}$ is shown in Figure 1. For this experiment, the pyrolysis and vaporization temperatures were set at $350{ }^{\circ} \mathrm{C}$ and $1800^{\circ} \mathrm{C}$, respectively, whereas $2.5 \mathrm{mg}$ of amitriptyline hydrochloride spiked with $300 \mathrm{ng}$ of As, $150 \mathrm{ng}$ of Mo and $30 \mathrm{ng}$ of the other investigated elements were analyzed. As can be observed in Figure 1, Cr and Pd exhibit similar behavior as a function of the Freon flow rate, differently of As that is a more volatile element. Similar behavior was observed for $\mathrm{Cd}$ (not shown in Figure 1), that is, the maximum Cd signal intensity was observed when the Freon flow rate was around $1.0 \mathrm{~mL} \mathrm{~min}{ }^{-1}$. It was observed that the $\mathrm{Cr}$ signal intensity as well as those of $\mathrm{Cu}, \mathrm{Mo}, \mathrm{Ni}, \mathrm{V}, \mathrm{Mn}$ and $\mathrm{Pb}$ decreased at lower Freon flow rate when compared to $\mathrm{Pd}, \mathrm{Pt}, \mathrm{Rh}$ and $\mathrm{Ru}$ (not shown in Figure 1), probably due to the generation of halogenated compounds at lower Freon flow rate. In general, $80 \%$ of the maximum signal of $\mathrm{Cr}, \mathrm{Cu}$, Mo, Ni, V, Mn and $\mathrm{Pb}$ was observed when $0.5 \mathrm{~mL} \mathrm{~min}^{-1}$ of Freon was added to the carrier gas. On the other hand, the Freon flow rate should be at least $1.0 \mathrm{~mL} \mathrm{~min}^{-1}$ for $\mathrm{Pd}, \mathrm{Pt}, \mathrm{Rh}$ and $\mathrm{Ru}$ exhibit $80 \%$ of their maximum signal. In general, the analyte signal intensity increased with the Freon flow rate increase, differently of As and $\mathrm{Cd}$. The signals of these two more volatile elements decreased with the Freon flow rate increase because the added gas impairs the nucleation process, preventing the analyte transport to the ICP. Therefore, it can be stated that effect of Freon on nucleation is more pronounced for more volatile elements.

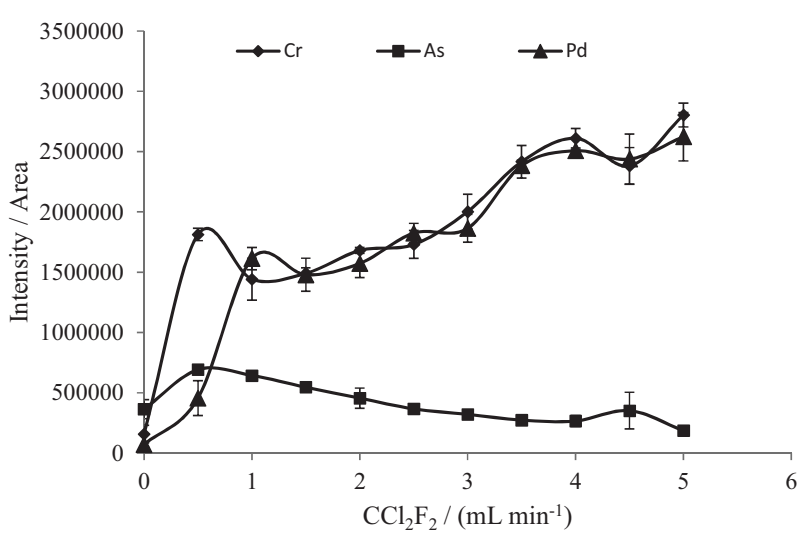

Figure 1. Effect of $\mathrm{CCl}_{2} \mathrm{~F}_{2}$ flow rate on the analytes signals intensities. Sample: $2.5 \mathrm{mg}$ of amitriptyline hydrochloride added with $300 \mathrm{ng}$ of As and $30 \mathrm{ng}$ of $\mathrm{Cr}$ and $\mathrm{Pd}$; pyrolysis and vaporization temperatures: 350 and $1800{ }^{\circ} \mathrm{C}$, respectively. Each point is the mean and standard deviation of three measurements.
However, suppression of the As and Cd signals may also have occured as a consequence of energy transfer change in the ICP caused by Freon. Thus, as a compromise condition, the Freon flow rate was fixed in $3.0 \mathrm{~mL} \mathrm{~min}$.

The analyte vapor transport is usually improved in the presence of some compounds, ${ }^{33}$ which can promote the formation of clusters. Therefore, the effect of organic compounds such as citric acid, ascorbic acid, oxalic acid, ethylenediaminetetraacetic acid, and $\mathrm{NaCl}$ were evaluated. These substances not only increase the analyte transport, but also serve as matrix matching. In this way, calibration can be carried out with aqueous standards instead of solid standards. However, the analyte transport was only little improved when up to $100 \mathrm{mg}$ of each compound above cited was added. Besides, the carrier effect was not the same for all elements, probably because Freon masked the effect caused by the added substance. Thus, only Freon was used in further experiments, which acts as reaction gas (lowering the vaporization temperature) and carrier of several elements.

\section{Heating program of the ETV system}

The pyrolysis $\left(300\right.$ to $800{ }^{\circ} \mathrm{C}$ ) and vaporization $(800$ to $2000{ }^{\circ} \mathrm{C}$ ) temperatures as well as the time of each step were evaluated in order to obtain a compromise condition for the determination of all elements simultaneously at a Freon flow rate of $3.0 \mathrm{~mL} \mathrm{~min}{ }^{-1}$. Experiments using standard solutions and sample spiked with standards were carried out. In these experiments, $300 \mathrm{ng}$ of As, $150 \mathrm{ng}$ of Mo and $30 \mathrm{ng}$ of each of the other elements were directly analyzed or added to $2.5 \mathrm{mg}$ of amitriptyline hydrochloride on the graphite platform. The ETV program evaluated and set consisted of four heating steps: (i) fast heating ( $5 \mathrm{~s}$ ) to reach $200{ }^{\circ} \mathrm{C}$ and holding for $10 \mathrm{~s}$; (ii) heating (about $60 \mathrm{~s}$ ) up to the pyrolysis temperature and holding for $15 \mathrm{~s}$, the temperature was slowly increased in this step with the aim to eliminate the sample matrix slowly in order to prevent the plasma extiction due to the matrix overloading; (iii) vaporization at maximum power $\left(3000{ }^{\circ} \mathrm{C} \mathrm{s}^{-1}\right)$ and holding for $20 \mathrm{~s}$ and (iv) cleaning at $2400{ }^{\circ} \mathrm{C}$ for $5 \mathrm{~s}$. The ETV program established is given in Table 2. When the pyrolysis temperature was evaluated that of the vaporization was fixed at $2000{ }^{\circ} \mathrm{C}$; when the vaporization temperature was evaluated that of pyrolysis was set at $350^{\circ} \mathrm{C}$. Figure 2 shows the pyrolysis and vaporization temperature curves of $\mathrm{As}, \mathrm{Cr}$ and $\mathrm{Pd}$, where one can observe that the behavior of the elements is different with respect to the pyrolysis temperature. Arsenic is lost at lower temperature than $\mathrm{Cr}$ and $\mathrm{Pd}$. Similar behavior was observed for $\mathrm{Cr}, \mathrm{Cu}, \mathrm{Mn}$, $\mathrm{Ni}$, Mo and $\mathrm{Pb}$, which were lost at pyrolysis temperature higher than $500{ }^{\circ} \mathrm{C}$. With respect to the other investigated 
elements, no losses were observed up to $800{ }^{\circ} \mathrm{C}$. These findings agree with the results reported by Matousek and Satumba $^{30}$ and Ren and Salin. ${ }^{32}$

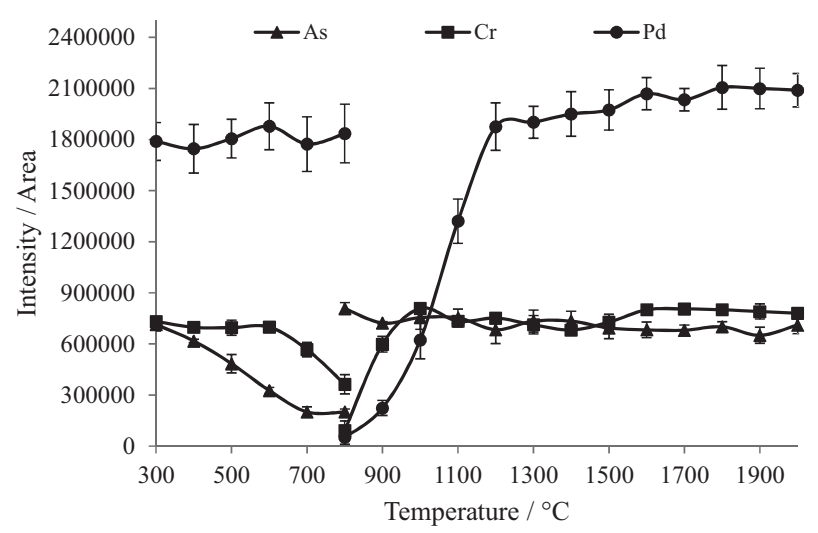

Figure 2. Pyrolysis and vaporization temperatures. Sample: $2.5 \mathrm{mg}$ of amitriptyline hydrochloride spiked with $300 \mathrm{ng}$ of As and $30 \mathrm{ng}$ of $\mathrm{Cr}$ and $\mathrm{Pd} ; \mathrm{CCl}_{2} \mathrm{~F}_{2}$ flow rate: $3 \mathrm{~mL} \mathrm{~min}^{-1}$; pyrolysis and vaporization temperature: 350 and $2000{ }^{\circ} \mathrm{C}$, respectively. Each point is the mean and standard deviation of three measurements.

\section{Sample mass evaluation}

The evaluation of the effect of sample mass was carried out using amitriptyline hydrochloride spiked with the analytes, whereas the sample mass ranged from 0.1 to $7.5 \mathrm{mg}$. The minimum sample mass was limited by the difficulty in weighing sample mass lower than $0.1 \mathrm{mg}$, while the maximum sample mass was by the graphite platform capacity (about $10 \mathrm{mg}$ for this kind of sample). In addition, higher sample mass would lead to plasma instability or even its extinction, mainly when the whole matrix could not be eliminated at the pyrolysis step (Table 2). The effect of the sample mass was not the same for all investigated elements and according to the results obtained in this step, they could be grouped in distinct groups: (i) the As, Cd, V and Mo signal intensity was suppressed when the amount of sample was higher than $5.0 \mathrm{mg}$; (ii) the $\mathrm{Cr}, \mathrm{Cu}, \mathrm{Mn}, \mathrm{Ni}$ and $\mathrm{Pb}$ signal intensity increased gradually with the sample mass increasing; (iii) the $\mathrm{Pd}, \mathrm{Rh}$ and $\mathrm{Ru}$ signal intensity increased with the sample mas increasing up to $0.5 \mathrm{mg}$ and then remained almost constant; $(i v)$ the maximum signal of Pt was observed for $0.5 \mathrm{mg}$ of sample, which decreased for higher sample mass. The effect of sample mass on the As, $\mathrm{Cr}$, Pd signals can be seen in Figure 3. As a compromise condition for multielement determination, in the present work, the sample mass was fixed at $2.5 \mathrm{mg}$.

The sample constituents can increase the analyte vapor transport to the ICP, increasing the analyte signal as a consequence. ${ }^{36}$ On the other hand, too much amount of sample overload the plasma where there is no more sufficient energy for analyte excitation. Some authors ${ }^{36}$ stated that signal increasing and/or suppression is related to the element volatility. However, with the exception of As, in the present work, different behavior was observed for elements with similar volatility. Therefore, additional investigations are necessary by considering also the energy of the emission line involved. The effect of Freon in the ICP must also be considered because a mixed gas plasma is generated. In addition, the excitation conditions in the ICP changes in the presence of carbon as observed by $\mathrm{Lu}$ and Jiang, ${ }^{37}$ Ho and Jiang ${ }^{38}$ and Li et al. ${ }^{39}$

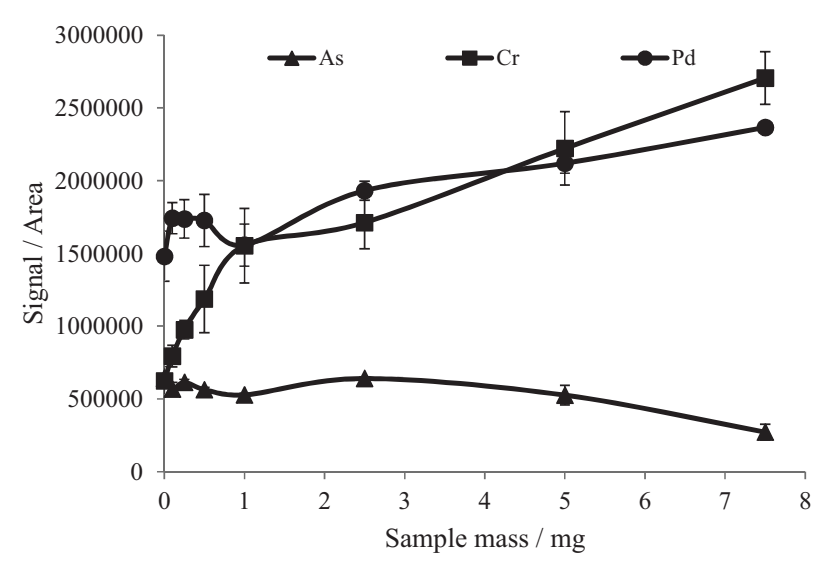

Figure 3. Effect of the sample mass on the analyte signal intensity. Sample: spiked with $300 \mathrm{ng}$ of As and $30 \mathrm{ng}$ of $\mathrm{Cr}$ and $\mathrm{Pd} ; \mathrm{CCl}_{2} \mathrm{~F}_{2}$ flow rate of $3 \mathrm{~mL} \mathrm{~min}^{-1}$; pyrolysis and vaporization temperature: $300{ }^{\circ} \mathrm{C}$ and $1600{ }^{\circ} \mathrm{C}$, respectively. Each point is the mean and standard deviation of three measurements.

\section{Calibration, limits of detection and precision}

The external calibration (a) and standard addition (b) methods were evaluated using a multielement standard solution where the analyte concentration was in accordance with its sensitivity. Increasing volumes of this solution were transferred to the graphite platforms, with or without sample, and dried on the drying bank. Blank replicates consinting of $5 \mu \mathrm{L}$ of $0.72 \mathrm{~mol} \mathrm{~L}^{-1} \mathrm{HNO}_{3}$ were also analyzed. The mass range used for both calibration methods, the coefficient of determination $\left(\mathrm{r}^{2}\right)$ and the linear regression equation of calibration curves are summarized in Table 3. Better coefficient of determination was observed $\left(r^{2} \geq 0.99\right)$ for the external calibration. Although Freon acts as reaction and carrier gas, minimizing differences for the analyte in aqueous solution and in the presence of sample, the standard addition method was still necessary in view of the different sensitivity observed for the analyte in prescence and absence of the sample matrix. With respect to precision, the relative standard deviation (RSD) was typically lower than $10 \%$.

The limits of detection were calculated using the $3 \sigma$ criterion. The standard deviation $(\sigma)$ was obtained from 10 measurements of the empty graphite platforms. The 
Table 3. Parameter of the calibration curves obtained by external calibration and standard addition methods by using ETV-ICP OES

\begin{tabular}{lccccc}
\hline Analyte & Calibration curve / $\mathrm{ng}$ & $\begin{array}{c}\text { Equation } \\
\text { External calibration }\end{array}$ & $\mathrm{R}^{2}$ & $\begin{array}{c}\text { Equation } \\
\text { Standard addition }\end{array}$ & $\mathrm{R}^{2}$ \\
\hline $\mathrm{As}$ & $300-6250$ & $\mathrm{y}=609 \mathrm{x}+81276$ & 0.9991 & $\mathrm{y}=346 \mathrm{x}+26129$ & 0.984 \\
$\mathrm{Cd}$ & $1.5-50$ & $\mathrm{y}=264321 \mathrm{x}+83972$ & 0.9998 & $\mathrm{y}=27236 \mathrm{x}+20926$ & 0.998 \\
$\mathrm{Cr}$ & $2.4-50$ & $\mathrm{y}=66069 \mathrm{x}+37994$ & 0.9990 & $\mathrm{y}=42454 \mathrm{x}+13296$ & 0.995 \\
$\mathrm{Cu}$ & $0.4-12.5$ & $\mathrm{y}=729831 \mathrm{x}+52835$ & 0.9995 & $\mathrm{y}=16476 \mathrm{x}+81548$ & 0.995 \\
$\mathrm{Mn}$ & $0.15-5.0$ & $\mathrm{y}=1157120 \mathrm{x}+118161$ & 0.9985 & $\mathrm{y}=36632 \mathrm{x}+18103$ & 0.999 \\
$\mathrm{Mo}$ & $138-1375$ & $\mathrm{y}=428 \mathrm{x}+18975$ & 0.9958 & $\mathrm{y}=396 \mathrm{x}+11968$ & 0.998 \\
$\mathrm{Ni}$ & $3-100$ & $\mathrm{y}=53603 \mathrm{x}+59414$ & 0.9991 & $\mathrm{y}=4525 \mathrm{x}+39445$ & 0.991 \\
$\mathrm{~Pb}$ & $41-1375$ & $\mathrm{y}=2702 \mathrm{x}+26568$ & 0.9949 & $\mathrm{y}=2026 \mathrm{x}-17674$ & 0.999 \\
$\mathrm{Pd}$ & $6-125$ & $\mathrm{y}=43183 \mathrm{x}-175327$ & 0.9942 & $\mathrm{y}=14438 \mathrm{x}+11993$ & 0.995 \\
$\mathrm{Pt}$ & $78-2625$ & $\mathrm{y}=1476 \mathrm{x}+192952$ & 0.9931 & $\mathrm{y}=1412 \mathrm{x}+1987$ & 0.997 \\
$\mathrm{Rh}$ & $3.7-125$ & $\mathrm{y}=73358 \mathrm{x}-5281$ & 0.9998 & $\mathrm{y}=10155 \mathrm{x}+11538$ & 0.991 \\
$\mathrm{Ru}$ & $3.7-125$ & $\mathrm{y}=46296 \mathrm{x}-3724$ & 0.9997 & $\mathrm{y}=8352 \mathrm{x}+33759$ & 0.975 \\
$\mathrm{~V}$ & $7.4-250$ & $\mathrm{y}=97428 \mathrm{x}+428582$ & 0.9952 & $\mathrm{y}=96796 \mathrm{x}+16450$ & 0.997 \\
\hline
\end{tabular}

Table 4. Limits of detection of the ETV-ICP OES and MIC ICP-MS methods and limits established by the USP and FBRAS pharmacopeias

\begin{tabular}{|c|c|c|c|c|c|}
\hline \multirow{2}{*}{ Element } & \multicolumn{2}{|c|}{ ETV-ICP OES } & \multirow{2}{*}{$\frac{\text { MIC ICP-MS }}{\text { LODs } /\left(\mu \mathrm{g} \mathrm{g}^{-1}\right)}$} & \multicolumn{2}{|c|}{ Limits / $\left(\mu \mathrm{g} \mathrm{g}^{-1}\right)$} \\
\hline & LODs / ng & LODs / $\left(\mu \mathrm{g} \mathrm{g}^{-1}\right)$ & & FBRAS & USP \\
\hline As & 267 & 107 & 0.4 & 1.5 & 0.15 \\
\hline $\mathrm{Cd}$ & 0.5 & 0.2 & 0.005 & 0.5 & 0.25 \\
\hline $\mathrm{Cr}$ & 1.7 & 0.7 & 0.4 & 25 & a \\
\hline $\mathrm{Cu}$ & 0.1 & 0.04 & 0.9 & 250 & 25 \\
\hline $\mathrm{Mn}$ & 0.1 & 0.04 & 0.4 & 250 & - \\
\hline Mo & 114 & 46 & 0.9 & 25 & 1.0 \\
\hline $\mathrm{Ni}$ & 2.1 & 0.85 & 1.1 & 25 & 5.0 \\
\hline $\mathrm{Pb}$ & 6.3 & 2.5 & 0.2 & 1.0 & 0.5 \\
\hline $\mathrm{Pd}$ & 4.9 & 2.0 & 0.002 & 10 & 1.0 \\
\hline $\mathrm{Pt}$ & 18 & 7.2 & 0.002 & 10 & 1.0 \\
\hline $\mathrm{Rh}$ & 0.2 & 0.08 & 0.001 & $\Sigma<10$ & 1.0 \\
\hline $\mathrm{Ru}$ & 0.5 & 0.2 & 0.001 & $\Sigma<10$ & 1.0 \\
\hline V & 6.2 & 2.5 & 1.0 & 25 & 1.0 \\
\hline
\end{tabular}

${ }^{a}$ Not a safety concern.

limits of detection (LODs) of the proposed ETV-ICP OES are given in Table 4, where one can compare with those of the MIC ICP-MS method and the limits recommended by $\mathrm{USP}^{4}$ and FBRAS. ${ }^{5}$ As can be observed in Table 4, the proposed method attends the limits recommended by $\mathrm{USP}^{4}$ for $\mathrm{Cd}, \mathrm{Cu}, \mathrm{Ni}, \mathrm{Rh}$ and $\mathrm{Ru}$ and those of $\mathrm{Cd}, \mathrm{Cr}, \mathrm{Cu}, \mathrm{Mn}, \mathrm{Ni}$, $\mathrm{Pd}, \mathrm{Pt}, \mathrm{Rh}, \mathrm{Ru}$ and $\mathrm{V}$ recommended by FBRAS. ${ }^{5}$

\section{Samples analysis}

For quantification of the investigated elements in the pharmaceuticals samples, $2.5 \mathrm{mg}$ of each sample were weighed directly into the graphite platforms, transferred to ETV and then vaporized by applying the heating program given in Table 2 under Freon at $3.0 \mathrm{~mL} \mathrm{~min}{ }^{-1}$. Ten samples were analyzed, whereas chromium was the unique element detected (concentration: $5.7 \pm 0.4 \mu \mathrm{g} \mathrm{g}^{-1}$ ) and only in cyclobenzaprine hydrochloride. The concentration of $\mathrm{Cr}$ was lower than the maximum limit recommended by FBRAS $\left(25 \mu \mathrm{g} \mathrm{g}^{-1}\right){ }^{5}$ The concentrations of all other elements were lower than the respective LODs.

Considering the 16 elements recommended by the Pharmacopoeias, ${ }^{4,5}$ only Ir, $\mathrm{Hg}$ and Os were not included in the present method. Osmiun is very volatile and the difficult 
determination of Os is well documented ${ }^{40}$ Mercury was not included in view of its higher volatility compared with the other investigated elements. Furthermore, halogenated compounds decrease the $\mathrm{Hg}$ transport to the ICP. ${ }^{35}$ Iridium was not included in the method due to the low sensitivity and low precision observed.

\section{Accuracy}

The accuracy of the results obtained using ETV-ICP OES were checked using an independent method. The Pharmacopoeias ${ }^{4-6}$ recommend sample decomposition using microwave assisted digestion for water insoluble samples and adequate techniques for element detection. However, it was not possible to decompose all analyzed samples by using the recommended sample decomposition method. The obtained sample solutions had elevated residual carbon content (RCC) and precipitate, likely products of nitration reactions. ${ }^{16}$ The FBRAS $^{5}$ recommends the use of MIC for samples of difficult decomposition, instead of microwave assisted digestion. MIC has already been used for pharmaceuticals decomposition whereas the RCC content in the final sample solution was very low. ${ }^{16}$ It is worth citing that low RCC content is very important in ICP-MS determination because carbon promotes spectral and non-spectral interferences. Therefore, the analytes determination in the pharmaceuticals samples was carried using MIC for sample decomposition. External calibration was used for element quantification using ICP-MS. The $\mathrm{Cr}$ concentration found in cyclobenzaprine hydrochloride was $6.12 \pm 0.12 \mu \mathrm{g} \mathrm{g}^{-1}$, which is not different of that found using ETV-ICP OES at 95\% of confidence level ( $t$-test). The other investigated elements were also not detected by using MIC and ICP-MS. In addition, analyte recovery test was also done. Analyte solutions were added to $2.5 \mathrm{mg}$ of sample mass in order to achieve concentration values about five-fold higher than the LOD of each element. Recoveries in the range of 91 to $103 \%$ were observed. Therefore, these results attest the good accuracy of the proposed ETV-ICP OES method.

\section{Conclusions}

An ETV-ICP OES method for direct determination of metals and metalloids in solid pharmaceuticals was developed. High sample throughput, good sensitivity, low or no sample preparation that reduces the risk of contamination and analyte losses are the main advantages of the proposed method.

Freon was used as reaction gas, which promoted the analytes vaporization at lower temperature. By adequate optimization of ETV-ICP OES parameters, 13 elements were accurately determined in 10 pharmaceutical samples. From the list of 16 elements that must be controlled in pharmaceuticals, only Ir, $\mathrm{Hg}$ and Os could not be included in the method, due to low sensitivity and/or losses in the pyrolysis step. The investigated elements were not detected in the analyzed samples, with the exception of Cr. Cyclobenzaprine hydrochloride was the only sample where $\mathrm{Cr}$ was detected, but the concentration found was lower than the concentration limit recommended by the pharmacopoeias. The LODs of $\mathrm{Cd}, \mathrm{Cr}, \mathrm{Cu}, \mathrm{Mn}, \mathrm{Ni}, \mathrm{Pd}$, $\mathrm{Pt}, \mathrm{Rh}, \mathrm{Ru}$ and $\mathrm{V}$ are lower than the maximum limits recommended by the FBRAS. ${ }^{5}$ However, the method does not attend the limits established by $\mathrm{USP}^{4}$ for $\mathrm{As}, \mathrm{Mo}, \mathrm{Pb}$, $\mathrm{Pd}, \mathrm{Pt}$ and V.

\section{Acknowledgements}

The authors gratefully acknowledge the support of the Conselho Nacional de Desenvolvimento Científico e Tecnológico (CNPq) and Coordenação de Aperfeiçoamento de Pessoal de Nível Superior (CAPES).

\section{References}

1. World Health Organization (WHO), http://www.who.int/topics/ pharmaceutical_products/en/ accessed in December 2014.

2. Meermann, B.; Sperling, M.; Anal. Bioanal. Chem. 2012, 403, 1501

3. International Conference on Harmonisation of Technical Requirements for Registration of Pharmaceuticals for Human Use (ICH), ICH Harmonized Tripartite Harmonized, Guideline for Elemental Impurities; ICH Q3D Guideline, Geneva, 2014.

4. The United States Pharmacopoeia 35; Elemental ImpuritiesLimits 232, Pharm. Forum, 37, 2011.

5. Agência Nacional de Vigilância Sanitária - Farmacopeia Brasileira, $5^{\text {a }}$ ed.; Brasília, 2010.

6. European Pharmacopoeia, $5^{\text {th }}$ ed.; Council of Europe: Strasbourg, 2005.

7. Scripcariu, M.; Tanase, I. G.; Fleschin, S.; Magearu, V.; Rev. Roum. Chim. 2008, 53, 149.

8. Tanase, A.; Miu, A.; Rev. Roum. Chim. 2012, 57, 971.

9. Raghuram, P.; Soma Raju, I. V.; Sriramulu, J.; Pharmazie 2010, 65,15 .

10. Antosz, F. J.; Xiang, Y.; Diaz, A. R.; Jensen, A. J.; J. Pharm. Biomed. Anal. 2012, 62, 17.

11. Carvalho, G. G. A.; Nunes, L. C.; Souza, P. F.; Krug, F. J.; Alegre, T. C.; Santos Jr., D.; J. Anal. At. Spectrom. 2010, 25, 803.

12. Lewen, N.; Mathew, S.; Schenkenberger, M.; Raglione, T.; J. Pharm. Biomed. Anal. 2004, 35, 739. 
13. Van Hoecke, K.; Catry, C.; Vanhaecke, F.; J. Anal. At. Spectrom. 2012, 27, 1909.

14. Mester, Z.; Sturgeon, R. In Comprehensive Analytical Chemistry - Sample Preparation for Trace Element Analysis; Barceló, D.; ed.; Elsevier: Amsterdam, 2003, p. 1338.

15. Mitra, S. In Sample Preparation Techniques in Analytical Chemistry; Kebbekus, B. B.; ed.; John Wiley \& Sons: New Jersey, 2003, ch. 5.

16. Barin, J. S.; Tischer, B.; Picoloto, R. S.; Antes, F. G.; Silva, F. E. B.; Paula, F. R.; Flores, E. M. M.; J. Anal. At. Spectrom. 2014, 29, 352.

17. Pereira, J. S. F.; Pereira, L. S. F.; Schmidt, L.; Moreira, C. M.; Barin, J. S.; Flores, E. M. M.; Microchem. J. 2013, 109, 29.

18. Antes, F. G.; Duarte, F. A.; Mesko, M. F.; Nunes, M. A. G.; Pereira, V. A.; Müller, E. I.; Dressler, V. L.; Flores, E. M. M.; Talanta 2010, 83, 364.

19. Kurfürst, U.; Solid Sample Analysis Direct and Slurry Sampling Using GF-AAS and ETV-ICP, Springer: Heidelberg, 1998.

20. Grindlay, G.; Mora, J.; Gras, L.; Loos-Vollebregt, M. T. C.; Anal. Chim. Acta 2009, 652, 154.

21. Masson, P.; Dauthieu, M.; Trolard, F.; Denaix, L.; Spectrochim. Acta, Part B 2007, 62, 224.

22. Wu, Y.; Hu, B.; Jiang, Z.; Chen, S.; J. Anal. At. Spectrom. 2002, $17,121$.

23. Resano, M.; Aramendíaz, M.; Devos, W.; Vanhaecke, F.; J. Anal. At. Spectrom. 2006, 21, 891.

24. Barth, P.; Hassler, J.; Kudrik, I.; Krivan, V.; Spectrochim. Acta, Part B 2007, 62, 924.

25. Asfaw, A.; Wibetoe, G.; Beauchemin, D.; J. Anal. At. Spectrom. 2012, 27, 1928.
26. Lin, M. -L.; Jiang, S. -J.; J. Anal. At. Spectrom. 2011, 9, 1813.

27. Majidi, V.; Smith, R. G.; Xu, N.; McMahon, M. W.; Bossio, R.; Spectrochim. Acta, Part B 2000, 55, 1787.

28. Flores, E. M. M.; Barin, J. S.; Mesko, M. F.; Knapp, G.; Spectrochim. Acta, Part B 2007, 62, 1051.

29. Detcheva, A.; Barth, P.; Hassler, J.; Anal. Bioanal. Chem. 2009, $394,1485$.

30. Matousek, J. P.; Satumba, R. T.; Spectrochim. Acta, Part B 1989, 44, 1005.

31. Schäffer, U.; Krivan, V.; Anal. Chem. 1999, 71, 849.

32. Ren, J. M.; Salin, E. D.; Spectrochim. Acta, Part B 1994, 49, 555.

33. Kántor, T.; Maestre, S.; Loos-Vollebregt, M. T. C.; Spectrochim. Acta, Part B 2005, 60, 1323.

34. Kántor, T.; Güçer, S.; Spectrochim. Acta, Part B 1999, 54, 763.

35. Grégoire, D. C.; Sturgeon, R. E.; Spectrochim. Acta, Part B 1999, 54, 773.

36. Kántor, T.; Loos-Vollebregt, M. T. C.; Spectrochim. Acta, Part B 2003, 58, 1901.

37. Lu, H. H.; Jiang, S. J.; Anal. Chim. Acta 2001, 429, 247.

38. Ho, C. Y.; Jiang, S. J.; J. Anal. At. Spectrom. 2002, 17, 688.

39. Li, Y. C.; Jiang, S. J.; Chen, S. F.; Anal. Chim. Acta 1998, 372, 365.

40. Houk, R. S.; Jarvis, K. E.; Gray, A. L.; Handbook of Inductively Coupled Plasma Mass Spectrometry, Blackie \& Son Ltd.: Glasgow, 1992.

Submitted: September 11, 2014

Published online: January 13, 2015

FAPERGS has sponsored the publication of this article. 